\title{
Paul Ricoeur: A Synthesis of a History of Life and a History of Death through Phenomenological Hermeneutics
}

\section{Christiane Joseph C. Jocson}

\begin{abstract}
Paul Ricoeur's work entitled Memory, History, Forgetting presents his understanding of the works of Wilhelm Dilthey and Martin Heidegger with regard to history. What is admirable about Ricoeur here is that he was able to see that a notion of history emphasizing about life is not at all contradictory to an understanding of history based on a notion of death. What this paper will try to do is to expose how Paul Ricoeur bridges the link between the philosophy of history of Dilthey and Heidegger through his phenomenological hermeneutics.
\end{abstract}

Keywords: Ricoeur, hermeneutics, life and death, history

\section{Ricoeur on Dilthey: History and the "Connectedness of Life"}

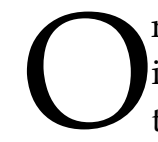

ne of the common misunderstandings with regard to history is that it is a mere narrative of the dead or of lives long gone. But reading the philosophy of Paul Ricoeur, we can see that even the people of the past are not excluded from the possibility of life. The past is more than something to be cherished and remembered, but it is also something that must be projected towards possibilities beyond its time. ${ }^{1}$ For Ricoeur, there is still hope to be found even in the irrevocable past. Although we cannot change what has already transpired, these narratives of the past, for Ricoeur, can still live on and continue to be written. In order to justify his claims, Ricoeur utilizes Wilhelm Dilthey's philosophy of history as a foundation for presenting that life is still possible to the people of the past.

${ }^{1}$ It is important for Ricoeur to present that the past is not a closed moment of human history. The challenge is always to find a means by which we are able to open up the past, to find the world of possibility that is latent in the moment that we refer to as the past.

(C) 2015 Christiane Joseph C. Jocson

http://www.kritike.org/journal/issue 17/jocson december2015.pdf

ISSN 1908-7330

$(c c)$ BY-NC-ND 


\section{A HISTORY OF LIFE AND A HSITORY OF DEATH}

One of the enunciations of Dilthey's concept of the "connectedness of life" is his presentation that history is more than just the passage of time, the passing of one moment to another. History, says Dilthey, does not proceed by mechanical causation (Kausalzusammenhang) but instead by dynamic causation (Wirkungszusammenhang). ${ }^{2}$ What Dilthey means here is that history must go beyond the perception of mere chronology; history is more than just a linear timeline of events. But there is something enigmatic about history that brings to shame any attempt to reduce it to a long line of mere cause and effect kind of understanding. Any kind of deterministic perspective of history fails to see that even the most thought-about event in history still has something that can evoke our surprise.

Chronology is not history for Ricoeur. A mere sequencing of events that fails to recognize the human struggle in each moment is not history. ${ }^{3}$ Historical time for Ricoeur cannot be reduced to a mere qualitative view of time; history is not statistics. Even a minute moment in history bears witness to the plight of many different faces. Thus, it is important that we shed light into the counterpart of Kronos and present a history beyond the numbers that can actually testify to the human quality implicit in history.

The problem here is that we commonly take the task of teaching history as nothing but a concern with dates, numbers, names, and other figures. Our fixation on treating historical time as Kronos had always resulted in alienating the human from history. We had forgotten that inside history there is a story to be told. It must be emphasized that history is home to a plurality of faces, voices, and stories that tell how human beings tried to live as human beings. Ricoeur's reading of Dilthey sheds light on his idea that life has a place in history.

Ricoeur begins by presenting that in Dilthey we are able to realize a conception of temporality that avoids the common segmentation between past, present, and future. This allows Dilthey to present historical time as a continuum of life between different timelines. In other words, the past is not closed off from the present and the future, the present is not closed off from the past and the future, and the future is not closed off from the past and the present. ${ }^{4}$ To alienate the past, the present, and the future from one another

2 Emerita S. Quito, Philosophers of Hermeneutics (Manila: De La Salle University Press, 1990), 45 .

${ }^{3}$ Richard Kearney in his idea of "carnal hermeneutics" elucidates on the idea that any kind of hermeneutics must be wary of the aspect of the flesh contained in the word. Hermeneutics for Kearney cannot be exclusively an encounter with the text but it also must be an encounter with a living flesh that struggles to be in every moment of history.

${ }^{4}$ It would be important also to emphasize that Ricoeur's understanding of Dilthey puts into question the boundaries between the past, present, and future. For Ricoeur, there is no such a thing as an absolute past, present, and future. They are intertwined with one another and it is their intertwinement that gives birth to history.

(c) 2015 Christian Joseph C. Jocson

http://www.kritike.org/journal/issue 17/jocson december2015.pdf

ISSN 1908-7330

(c) $)$ BY-NC-ND 
will be tantamount to destroying the temporal interweaving of possibilities that we refer to as history. As Emerita S. Quito would state:

Understanding is a fusion of horizons. No one can abstract or isolate an event with its backdrop or horizon from other events with their corresponding horizons. ${ }^{5}$

The task of a hermeneutist or a historian is always to be wary of any tendency to alienate one event from another and to allow people of different times and cultures to reach out to each other. Ricoeur here is also presenting that we are not just responsible for the people that are present before me; a response-able human being is also able to be responsible for people who are absent, both to those situated in the past and the future. Hermeneutics is one of the ways by which we are able to manifest our response-ability even to the people who are absent. Also, it is through hermeneutics that we are able to affirm a living social connection that transcends space and time.

An encounter with history is an encounter with life embedded in the text of the past. What is important in the project of Dilthey is that see tries to bring back the vital spirit that fuels history and the other human sciences. The task of the historian according to Dilthey is not simply to recount events but also and most importantly to relive it. The life of the people of the past is not something that must be thrown in an attitude of indifference because of reasons of irrelevance. History is a communion of human lives with one another, for history is a plurality of human narratives that tell of a flesh that lived, suffered, and died. We remember and we partake in the suffering of a people beyond our time. That is why for Dilthey, the historian must learn to encounter the different human faces behind all these names, dates, and figures. To quote:

Dilthey's final letter (summer 1897) contains one of his rare confessions: "Yes! the term Geschichtlichkeit is the most apt to convey the supreme task of the human sciences, which is to stand up, in self-reflection, in the name of 'victorious spontaneous vitality,' to the lack of spirituality of modern times"; to value, he says, "the consciousness of the supra-sensible and supra-rational nature of historicity itself" (Renthe-Fink, Geschichtlichkeit, 107). ${ }^{6}$

${ }^{5}$ Quito, Philosophers of Hermeneutics., 96-97.

${ }_{6}$ Paul Ricoeur, Memory, History, Forgetting, trans. by Kathleen Blamey and David Pellauer, (Chicago: The Chicago University Press, 2004), 373. Hereafter cited as MHP.

(C) 2015 Christiane Joseph C. Jocson http://www.kritike.org/journal/issue 17/jocson december2015.pdf ISSN 1908-7330 


\section{A HISTORY OF LIFE AND A HSITORY OF DEATH}

Ricoeur's appropriation of Dilthey's notion of the connectedness of life has brought on his understanding that life is not an exclusive possession of those who are present. Even those who are absent convey a certain vitality that can be found in a hermeneutical encounter. But unlike Dilthey, Ricoeur goes further in his presentation of life in history. Instead of just a reliving of history, Ricoeur would stress that we are able to affirm that history is a living narrative through our actions. It is through putting into action the lessons that we learn from the lives of the people of the past that they are enabled to be present even in their absence. We make their being live through us and in our actions. We allow them to speak again through our being and our actions.

History too is a science of the speaking living being; the juridical normativity that governs the genealogical field is not only one of its objects, not even a "new" object, but instead a presupposition attached to the positing of its object and in this sense an existential presupposition: history encounters only speaking living beings in the process of institution. Genealogy is the institution that makes life human life. In this sense, it is a component of standing for, constitutive of historical intentionality. ${ }^{7}$

In this sense, Ricoeur adds to Dilthey that the historian plays an important role in giving voice to the voiceless. The historian then appears as the one who, in a variety of ways, makes the dead speak. ${ }^{8}$ But this notion of Ricoeur is not simply limited to reading and telling the stories of these people who passed away that their spirit may live on. It is important to note that what we refer to as the narrative of the other is closer to our being than what we realize. For Ricoeur, there is no such thing as a narrative that is exclusive to myself and excludes everything other. History is a dialogue between human narratives; it is this intersubjective dialogue that transcends time that creates the ground for history.

The narrative of the other becomes a part of my own narrative, and mine becomes part of his. The responsibility of refiguring lives is both a social responsibility and a responsibility towards the self. In other words, for Ricoeur ethical responsibility and existential responsibility go hand in hand with one another. But this dialogue between narratives is not simply limited to people who are present and alive right at this moment. Ricoeur's phenomenological hermeneutics allows us to dialogue with both the people of the past and the people of the future. The world of the text offers a soil

\footnotetext{
${ }^{7}$ Ricoeur, $M H P, 379$.
}

${ }^{8}$ Ibid., 368.

(c) 2015 Christian Joseph C. Jocson

http://www.kritike.org/journal/issue 17/jocson december2015.pdf

ISSN 1908-7330

(c) BY-NC-ND 
fertile for a dialogue that transcends time. Through a hermeneutical encounter with the text we are able to reach out to human lives beyond our current situation. ${ }^{9}$

In any event, it is the function of discourse as the place of language to offer soil and a tomb to the dead of the past: "The ground is an inscription of meaning, the tomb a passage of voices." 10

Language here becomes more than just a means for us to convey meanings and ideas, but it also through language that death avoids becoming an absolute cessation of life. It is through language that we are able to make the world fertile to accommodate and give space for those who have passed on. Their absence does not discount them from my responsibility. I am called on by these mute voices of the past to make them be heard, heard not just by the people of the present but also for the people who are soon to come.

Richard Kearney, in his article entitled "Capable Man, Capable God," discusses that Ricoeur's phenomenological hermeneutics allows us to be attentive to the repressed voices of the past. Not everything has already been said in history; on the contrary, what we understand much of history is told through the voices of the victors and the dominant class. ${ }^{11}$ What Ricoeur's hermeneutics tries to achieve is to give justice to these repressed dreams and hopes in history by trying to make people of the present and of the future remember that these repressed people also have something to say about history. They are also people who lived like us and tried to participate in the becoming of history. In other words, they are to be considered as co-authors in the narrative that we refer to as history.

A meditation on repetition authorizes a further step, following the idea that the dead of the past once were living and that history, in a certain manner, moves closer

\footnotetext{
9 Ricoeur goes beyond the original intentions of Dilthey's concept of the "connectedness of life" through a presentation of his phenomenological hermeneutics. Ricoeur sees a "connectedness of life" through a dialogue of narratives and interpretations. The idea for Ricoeur is that there is always a whole world of narratives of which I am not the author that set the ground for my own narrative. In other words, for Ricoeur, it is important that we adopt an open attitude with regard to the narrative of the other. The story of another person is not strictly contradictory or alien to my own but they overlap with each other.

${ }^{10}$ Ricoeur, $M H P, 369$.

${ }^{11}$ See Richard Kearney, "Capable Man, Capable God," in A Passion for the Possible: Thinking with Paul Ricoeur, ed. Brian Treanor and Henry Isaac Venema (New York: Fordham University Press, 2010), 55.
}

(C) 2015 Christiane Joseph C. Jocson http://www.kritike.org/journal/issue 17/jocson december2015.pdf ISSN 1908-7330 
to their having-been-alive. The dead of today are yesterday's living, who were acting and suffering. ${ }^{12}$

History is not just about telling and finding historical facts; it must also consider that history is a human narrative of acting and suffering. We are not simply spectators of history but we are also actors that have a part to play in the unfolding of history. But we must note that the nature of history is not merely to be able to give life to the dead or to give voice to the voiceless; it must also convey a message of possibility. It is here that Ricoeur makes an appropriation of Martin Heidegger's philosophy of history to convey a message of hope in history.

\section{Ricoeur on Heidegger: History and "Being-towards-death"}

Having been able to present the element of vitality or life in history through a reading on Dilthey, Ricoeur sets forth to the other aspect of history. In the first instance, as it is apprehended in L'Absent de l'histoire, death is that which history misses. ${ }^{13}$ In order to present death as not simply death, Ricoeur makes use of Heidegger's philosophy, most notably his concept of Dasein as a "being-towards-death."

Here, we can offer resistance to Heidegger's analysis, for which the determination of the past as elapsed must be considered an inauthentic form of temporality, dependent upon the vulgar concept of time, the simple sum of fleeting nows. ${ }^{14}$

Heidegger's understanding of history and temporality is something that cannot be reduced to mere linear causation. History is not just an indifferent flow of time or a mechanistic transition from one era to another. But we, as human beings, have a part to play in the unfolding of history. Each human being has a particular place in history and each one of these narratives constitute what we refer to as history. We participate in the unfolding of history and at the same time we participate in a narrative of another. In other words, there is a human aspect that constitutes history. It is also because of this human element in history that it cannot be objectively determined; history is a history of surprises.

In order to emphasize this human element in history, Ricoeur appropriates Heidegger's notion of an authentic death. For even in death, the

\footnotetext{
12 Ricoeur, $M H P, 380$.

${ }^{13}$ Ibid., 366.

${ }^{14}$ Ibid., 364.
}

(c) 2015 Christian Joseph C. Jocson

http://www.kritike.org/journal/issue 17/jocson december2015.pdf

ISSN 1908-7330

(cc) BY-NC-ND 
authentic being affirms that there is something human, subjective, and existential even in his death. To treat death merely on the level of the biological would clearly miss what Heidegger is pointing out. Death in history bears a face, a face that had been wounded by time and had struggled to project himself towards his possibilities.

He first notes that death in history is not directly the indiscriminate death of anonymous people. It is, primarily, the death of those who bear a name; death that is an event. ${ }^{15}$

For Heidegger, death is something that we are all fated to face in our life. We all share in the very ownmost possibility of Dasein. But this does not mean that every tombstone that we see tells about the same tale. Any effort that tries to generalize death in history would only do violence to the human beings that struggled to do more than just be. Each human being for Heidegger struggles to become something apart from the crowd of anonymous people. Each tombstone that we encounter bears a name, bears a tale, and also bears witness to the human struggle to be in history.

This primacy of the future is implied in the theme of being-toward-death; this theme condenses, then, all the fullness of meaning glimpsed in the preparatory analysis of care under the heading of "being-ahead-of-itself. ${ }^{16}$

One of the important insights that Ricoeur derives from his interpretation of Heidegger is that what we call as past is not closed as past. What I mean by this is that our understanding of history or of past events is not already set in stone; there are still elements of the unthought that remain in history. In other words, history must be thought as a collective and an individual expression of possibility.

It is the structure of care that, by its very openness, imposes the problematic of totality and that confers on it the modality of potentiality, of possible being, as is summed up in the expression Ganzseinkonnen (potentiality of being-a-whole, possible being-a-whole): whole is to be understood not as a closed system but integrality, and in this sense, openness. ${ }^{17}$

\footnotetext{
${ }^{15}$ Ibid., 367

${ }^{16}$ Ibid., 356.

${ }^{17} \mathrm{Ibid}$.
}

(c) 2015 Christiane Joseph C. Jocson http://www.kritike.org/journal/issue 17/jocson december2015.pdf ISSN 1908-7330 
If I think of a simple way of translating Heidegger's idea of Care in Filipino it would be "Ang Bukasan sa Kinabukasan at ang Hinaharap sa Panghinaharap." The first expression: "Ang Bukasan sa Kinabukasan" (The Opening in Tomorrow) would somehow crudely express the idea of the future as an open possibility. That is, think of "Bukasan" as something like a keyhole, a doorknob, or any instrument to open things. Meanwhile, "Kinabukasan" would be something like a door where we only know that there is a door but we do not know of what lies beyond the door.

One aspect of hope in Ricoeur that is inspired from the existentialist philosopher Soren Kierkegaard is that to hope for something is also to hope in fear and trembling. We know that there are different possibilities that lie in wait for us, but the problem is that we never know exactly what these possibilities have lying in store for us. What this means is that hope does not equate with the absolute certainty of success. The true kind of hope for Ricoeur is something that acknowledges that even if someone exerted all due effort there to attain something, there is still the possibility of disappointment and failure. Rebecca Huskey would even emphasize that hope and despair are two things that are closely linked to one another. The ability to despair is what makes us human. ${ }^{18}$ To hope is to be open, open to the future, open to possibilities, and open to failure and disappointment.

And openness always leaving room for what is
"outstanding" (Ausstand, §48), hence for
unfinishedness. The term "incompleteness" is important
to the extent that the "toward" of being toward-death
seems to imply some destination, some course
completed. ${ }^{19}$

Care's being-ahead-of-itself is thereby affected by its reformulation as "anticipation of possibility." 20 The attitude of Dasein is open to the possibility of the future, the life of history does not stop at the establishment of the monument or grand narratives that try to conclude the historical development. But for Heidegger, history must admit that there is always something that is left unfinished after every past event. ${ }^{21}$

\footnotetext{
${ }^{18}$ Rebecca K. Huskey, Paul Ricoeur on Hope: Expecting the Good (New York: Peter Lang Publishing, 2009), 29.

${ }^{19}$ Ricoeur, $M H P, 356$.

${ }^{20} \mathrm{Ibid}$.

${ }^{21}$ History can be considered as something like a collective work-in-progress as there is a kind of indebtedness to carry on the task of opening up the possibilities of life for the next generation. "The tie between futureness and pastness is assured by a bridging concept, that of

(c) 2015 Christian Joseph C. Jocson http://www.kritike.org/journal/issue 17/jocson december2015.pdf ISSN 1908-7330

(c) BY-NC-ND
} 
Ricoeur's appropriation of Heidegger's presentation of the element of death in history is also important in acknowledging that even the capable human being also has his limitations. Even the most capable of all human beings is unable to fulfill completely a promise. But this sentiment of Ricoeur is not to express pessimism, but instead he points out that in reality it is not out place to completely fulfill promises. The promise of utopia is always a work in progress, a promise that must always be understood in a state of anticipatory resoluteness. The more we come closer to fulfilling the promise of a utopia, the more we must realize that there is still much to be done. ${ }^{22} \mathrm{We}$ hope that the beings soon to be would be responsible to carry on the promise of a good life to other future generations.

Instead of just facing our own possibilities and keeping our own promises, there is also a kind of ethical responsibility that goes hand in hand with the existential responsibility to be authentic. For Ricoeur, we are not simply responsible for keeping our own promises, but understanding Ricoeur's notion of utopia, we can understand that we are also called on to keep the word of another. The promise of bringing into reality our utopian projections is a promise that is not exclusively mine, but I am invited to keep it and try to fulfill it.

It is here that the idea of hope of Ricoeur comes into play. Utopia is always something that we hope for; the dream of a good life is always something that we strive to achieve but always fall short of attaining it completely. This does not mean that we should give up on attaining it, but instead Ricoeur would encourage us to welcome such failure. It is because we admit that there are some shortcomings in our attempt to fulfill our utopian promise that we are able to free the utopian promise from any attempts to dominate or to possess it. Part of the utopian promise is to leave it open for others to participate in its realization.

Looking at this idea of hope and utopia for Ricoeur, we can see a close similarity with his thoughts and that of the thoughts of Ernst Bloch. ${ }^{23}$ One aspect of hope that Bloch discusses in his philosophy that can help us better

being-indebt. Anticipatory resoluteness can only be the assumption of the debt that marks our dependence on the past in terms of heritage." See Ricoeur, MHP, 363.

${ }^{22}$ We can say that the image of a utopia for Ricoeur is not a static, fixed, or absolute conception. But instead, utopia must be thought as something creative. For there is no single ideal utopian vision that can fit all cultures. Ricoeur presents an important distinction between ideology and utopia, wherein ideology is always projecting a singular ideal world. In contrast, utopia is something creative; it is an ideal that cannot be fully determined.

${ }^{23}$ Rebecca Huskey, in her book Paul Ricoeur on Hope, presents a section that compares the notion of hope in Ricoeur and of Ernst Bloch. She discusses that like Bloch, Ricoeur views hope as something that we must strive to achieve. Heaven is not something that will naturally come when the time is right. But part of our task as human beings is to make this possibility possible. It is through action that the dream of a good life fails to be just a fleeting dream.

(c) 2015 Christiane Joseph C. Jocson

http://www.kritike.org/journal/issue 17/jocson december2015.pdf

ISSN 1908-7330

(cc) BY-NC-ND 


\section{A HISTORY OF LIFE AND A HSITORY OF DEATH}

understand the connection of Heidegger's history of death to Ricoeur is his notion of an active hope. For Bloch, hope is something that we must work towards. It is not something that will naturally fall on our heads as long as we exert an extraordinary amount of patience. Similar to Bloch, Ricoeur following Heidegger's notion of history tells us that history is not simply a natural movement that automatically moves from one moment to the next. But history progresses through the participation of people who open up space and possibilities for history to move onto.

Another idea here is that these doors that represent the possibilities of history do not open by themselves, but it is the task of Dasein to be the one to open the possibilities of history. It is here that the second expression, "Ang Hinaharap sa Panghinaharap" (The Facing of the Future) comes into play. What does it mean to face something? Here Heidegger answers that it is with anticipatory resoluteness before one's possibilities that one can say that he is truly facing something. "... Angst, invoked here by virtue not of its emotional character but of its potentiality for openness with respect to the ownmost being of Da-sein confronting itself." 24

But Ricoeur goes further than Heidegger in presenting that it is not just the future where we can find the possibilities of history. But even the past has unfulfilled possibilities that lie in wait for us to hear them. Between absolute presence and absolute absence, Ricoeur would state that human beings are always in a state of limbo between absence and presence. For human beings are always in the state of being; they are always an ongoing project, and this goes the same for what we refer to as history.

The debate between the philosopher and the historian has everything to gain from re-establishing the dialectic of presence and absence, inherent in every representation of the past, whether mnemonic or historical. The intention of the past as having been comes out of this reinforced, once having-been signifies having been present, living, alive. ${ }^{25}$

Heidegger asserts, to conduct upon this basis "a genuine ontological analysis of the way Da-sein stretches along between birth and death." 26 Dasein is not exclusively promoting death even though he is a "beingtowards-death." Neither does he take fully the side of birth, for Dasein is always at the crossroads of time. It is by acknowledging this that he is able to witness the unfolding of things. And it is also by this quality of Dasein to be

\footnotetext{
24 Ricoeur, $M H P, 354$.

${ }^{25}$ Ibid., 364.

${ }^{26}$ Ibid., 374.
}

(c) 2015 Christian Joseph C. Jocson

http://www.kritike.org/journal/issue 17/jocson december2015.pdf

ISSN 1908-7330

(c) BY-NC-ND 
in between that he is able to create a dialectic of birth and death that creates the dynamic foundation for a history.

Da-sein can then be said to exist "as born" just as it is said to exist as "dying." Now what is this interval, if not care? "As care, Da-sein is the 'Between.'”27

The significance of presenting the philosophy of Heidegger is not to oppose the philosophy of Dilthey but instead to present history as an interplay between life and death, and of presence and absence. Taking Dilthey's philosophy of life without taking into consideration Heidegger would only come to emphasize history as capable of supporting human life but unable to look further than just living and acquiring lived experiences. On the other hand, solely promoting Heidegger's Dasein and excluding Dilthey would make history an always-serious undertaking, failing to appreciate the simple fact of being.

Death in history, I would say, is inherent in what Ranciere calls "the founding narrative." It is death on the scale of the past as it is completed, elapsed. It is "the inclusion of death in science, not as residue but as a condition of possibility.... There is history because there is a past and a specific passion for the past. And there is history because there is an absence of things in words, of the denominated in names." 28

Ricoeur's understanding of the aspect of death of history through Heidegger enables him to conceive death as a possibility. In contrast to the common understanding of death, death for Ricoeur is not the cessation of possibility. But it is this moment of absence of what we refer to as death that conditions the possibility for history. It is also this aspect of absence that allows for the possibility for freedom. Quoting from Ricoeur's Oneself as Another: "But instead death enables me to see I am always moving toward my death, and this prevents me from ever grasping it as a narrative end." ${ }^{29}$ Death does not denote the end of the narrative; instead, it denotes possibility, but this possibility is not made possible by the self but it is the other that opens up the possibility to hope for something beyond death.

\footnotetext{
${ }^{27}$ Ibid., 375.

${ }^{28} \mathrm{Ibid} ., 368$.

${ }^{29}$ Paul Ricoeur, Oneself as Another, trans. by Kathleen Blamey (Chicago; London: The University of Chicago Press, 1992), 160.
}

(C) 2015 Christiane Joseph C. Jocson http://www.kritike.org/journal/issue 17/jocson december2015.pdf ISSN 1908-7330 


\section{A HISTORY OF LIFE AND A HSITORY OF DEATH}

\section{Ricoeur's Phenomenological Hermeneutics and the Open- endedness of History}

One thing that Ricoeur was able to emphasize in his synthesis of the notion of history in Dilthey and Heidegger is the idea that historical interpretations are meant to be challenged and reevaluated. ${ }^{30}$ What we understand about history today is just one of the many possibilities. The idea is for us to remember that we must be responsible to challenge interpretations of history, even our own interpretations. This is in order that we may give other people hope that history is a constantly progressing narrative of freedom.

The object of interpretation, the text, furthermore, takes on an autonomous character once produced, so that it is no longer adequate to merely refer to its original meaning; instead of containing a fixed meaning, a text invites plural reading and interpretation. ${ }^{31}$

One thing that is notable in the phenomenological hermeneutics of Ricoeur is his presentation of the notion of "an excess of meaning." Meaning for Ricoeur is not something that is fixed; even events that happened in the past are still open for interpretation. There is no single kind of interpretation that is able to totally capture the event. This is one of the reasons that history for Ricoeur is something open-ended; it is home to a plurality of interpretations that enrich and inform one another.

Because here the semantic relation emerges from the excess of potential meaning over its use and function within a given synchronic system, the hidden time of symbols can convey the historicality of tradition, which passes on and sediments tradition, as well as the historicality of tradition which keeps tradition alive and renews it. ${ }^{32}$

${ }^{30}$ Ricoeur in his philosophy is referring to one of the lessons that we can learn from the masters of suspicion - that one must be able to adopt a critical attitude towards any kind of historical interpretation or historical narrative. The objective here is to avoid any kind of narrative that justifies any kind of domination.

${ }^{31}$ Josef Bleicher, Contemporary Hermeneutics (London \& New York: Routledge, 1980), 220.

32 Paul Ricoeur, "Hermeneutique et Critique des ideologies' (1973), 64. As cited in Bleicher, Contemporary Hermeneutics, 225.

(c) 2015 Christian Joseph C. Jocson

http://www.kritike.org/journal/issue 17/jocson december2015.pdf

ISSN 1908-7330

(c) BY-NC-ND 
The goal of historical hermeneutics is not just a reminiscence of the past, but it must also come to reinvigorate history. The job of the interpreter is to unravel the entire string of life and history latent in language. ${ }^{33}$ By doing hermeneutics, we are not just trying to romanticize and reminisce about the glory days of antiquity. But the goal of doing hermeneutics is always to open up a possible world that is able to testify that there is freedom in the world. History must not be fixated with the past, but it also must see ahead. In this regard, the retrospective character of history cannot by itself be equated with the imprisonment of determinism. ${ }^{34}$

Hermeneutical encounter of historical narratives for Ricoeur is more than just a reliving of the past. For if this is so, then we can think that there is no use to read present romance literature since they can be treated as mere variations of Shakespeare's highly acclaimed "Romeo and Juliet." Or in the case of philosophy, for example, there is no need to read other western thinkers other than Plato since all other western thinkers are just a series of footnotes to Plato as Alfred North Whitehead would claim.

Infinitely more promising for us is the assertion that repeating is neither restoring after-the-fact nor reactualizing: it is "realizing anew." It is a matter of recalling, replying to, retorting, even of revoking heritages. The creative power of repetition is contained entirely in this power of opening up the past again to the future. $^{35}$

What we must think about history is that just as hearing Johann Pachebel's "Canon" is just a series of variations of a single piece, each variation opens up something new. Though history may be thought as repeating itself, it is by repeating itself that it renews itself and makes the earth fertile to support reconfigured life and lived experiences. The same goes also with the idea of phenomenological hermeneutics of Ricoeur. With every repetition of the hermeneutical encounter with the text we always learn something new. Even should a renowned scholar present his interpretation, the challenge according to Ricoeur is to maintain the constant attitude to challenge the interpretation of the other and even of the self. Our role in history is to keep it alive and one of the means that we keep it alive is through a constant struggle, not to find the perfect interpretation, but a struggle to always renew history through a presentation of new points of view.

\footnotetext{
${ }^{33}$ Quito, Philosophers of Hermeneutics, 90.

${ }^{34}$ Ricoeur, $M H P, 380$.

${ }^{35} \mathrm{Ibid}$.
}

(C) 2015 Christiane Joseph C. Jocson http://www.kritike.org/journal/issue 17/jocson december2015.pdf ISSN 1908-7330 


\section{A HISTORY OF LIFE AND A HSITORY OF DEATH}

The idea in the phenomenological hermeneutics of Ricoeur is not to make oneself take primacy in the understanding of the text. On the contrary, the main idea is to make oneself become a witness to the process of unfolding (Alethiea), never at beginning or the end as Heidegger's Dasein stands between life and death. One thing that we must remember in doing hermeneutics is that we must avoid imposing ourselves on the text. To interpret is to stand at a distance and to act as a witness to the unfolding of the text before one's self.

To understand is not to project oneself into the text but to expose oneself to it. The interpreter is always in medias res, never at the beginning or end. ${ }^{36}$

It is not when the historian writes the last page of his book that history is brought to a close. But the spirit of the narrative of history must be ever kept alive. For when we are capable to still open up history that we can know that there is still life to be lived and a freedom to be free. At the end of a reconstruction, which mobilizes the historical imagination, the thought of the historian can be considered a means of rethinking what was once thought. ${ }^{37}$ The project of interpretation is a continuous struggle to free the text from any interpretation that tries to monopolize it. Any attempt to monopolize it is a kind of violence that denies the realization of freedom in history.

Neither in literary criticism nor in the social sciences is there a last word. Or if there is, we call that violence. ${ }^{38}$

There is no distinct or absolute end in history; what makes history end abruptly is when we fail to critically engage and dialogue with history. It is through phenomenological hermeneutics according to Ricoeur that death fails to become absolutely a cessation of life. It is by declaring the last word that history is brought to its end. The philosopher and the historian must maintain an attitude that avoids any declaration or possession of the truth. It is by a dispossession of the truth that we allow history to live on and see a horizon beyond what we envision.

\footnotetext{
${ }^{36}$ Quito, Philosophers of Hermeneutics, 92.

${ }^{37}$ Ibid., 380.

38 Paul Ricoeur, Hermeneutics and Human Sciences, trans. by John B. Thompson (Cambridge: Cambridge University Press, 1981), 74.

(c) 2015 Christian Joseph C. Jocson http://www.kritike.org/journal/issue 17/jocson december2015.pdf ISSN 1908-7330
} 


\section{Conclusion}

To conclude this paper, there are three notable points that Ricoeur presents in his synthesis of the history of life in Wilhelm Dilthey and the history of death in Martin Heidegger.

First, through phenomenological hermeneutics we are able to affirm what Dilthey refers to as the "connectedness of life" by allowing for dialogue between people of different time periods. Life and the possibility to be does not end in death, but one is left to hope in his absence that the Other becomes responsible to make him capable again. Each one of us is an enabling presence to the other. We are able to hope because of the presence of the Other and we are able to be response-able because there is an Other that gives us hope. History thus becomes a narrative that describes how human beings try to bring into fruition the promise of an infinite responsibility.

Second, death turns to life and life turns to death, history for Ricoeur is an interplay between life and death, and of presence and absence. History is a living narrative because things that are absent are never truly absent, but it is our responsibility to allow for things that are absent to be present. On the other hand, there is the aspect of death in history because even things that are present are not fully present. There are things that are present before me that exhibit a level of transcendence that eludes my ability to grasp it. It is a form of a resistance that tells me that there are possibilities in history beyond what I deem is possible.

Lastly, history for Ricoeur can be thought as an ongoing narrative of the constant interplay between human capability and human fallibility. The past, the present, and the future all have possibilities beyond what we ordinarily see. Thus, history presents us with the collective task of interpreting it. For interpretation or hermeneutics is not a task given exclusively for a self to refigure itself. But it is at the same time a means to refigure the world of the social. To open up and to face these possibilities in our own selves, in the world of the social, and in history is a responsibility that I can only hope I can achieve in fear and trembling.

The Graduate School, University of Santo Tomas, Philippines

\section{References}

Ricoeur, Paul, Freedom and Nature: The Voluntary and the Involuntary, trans. by Erazim V. Kohak (USA: Northwestern University Press, 1966). Hermeneutics and Human Sciences, trans. by John B. Thompson (Cambridge: Cambridge University Press, 1981).

(c) 2015 Christiane Joseph C. Jocson

http://www.kritike.org/journal/issue 17/jocson december2015.pdf

ISSN 1908-7330

(cc) BY-NC-ND 


\section{A HISTORY OF LIFE AND A HSITORY OF DEATH}

Memory, History, Forgetting, trans. by Kathleen Blamey and David Pellauer (Chicago: The Chicago University Press, 2004).

Oneself as Another, trans. by Kathleen Blamey (Chicago; London: The University of Chicago Press, 1992).

Bleicher, Josef, Contemporary Hermeneutics (London; New York: Routledge, 1980).

Huskey, Rebecca K., Paul Ricoeur on Hope: Expecting the Good (New York: Peter Lang Publishing, 2009).

Kearney Richard, "Capable Man, Capable God," in A Passion for the Possible: Thinking with Paul Ricoeur, ed. by Brian Treanor and Henry Isaac Venema (New York: Fordham University Press, 2010).

Quito, Emerita S., Philosophers of Hermeneutics (Manila: De La Salle University Press, 1990). 